\title{
Sykepleiere må sette ord på etiske problemer
}

Vi må øve oss på å bruke det etiske språket og identifisere etiske verdier som sikrer en god og forsvarlig sykepleie.

\section{Anne Kari Tolo Heggestad}

Professor

Fakultet for helsefag, VID vitenskapelige høgskole
Dilemma
Etikk
Etisk språk
Etisk spørsmål
Etisk problem

\section{Hovedbudskap}

Vi sykepleiere må kunne identifisere moralsk problematiske situasjoner for å kunne ivareta pasienter på best mulig måte og unngå krenkelser. Ofte strever vi med å sette ord på etiske spørsmål og problemer. Artikkelen tar for seg hva som kjennetegner et etisk problem, og betydningen av å øve seg i det etiske språket for å kunne identifisere etikken og det etisk problematiske i en situasjon.

Jeg opplever ofte at sykepleierstudenter og sykepleiere synes det er utfordrende å bruke etiske begreper og sette ord på etiske problemer. Det er noen ganger som om etikkspråket og etiske begreper lukker en samtale mer enn de åpner den. Med etisk språk mener jeg her ord og begreper fra etikken, som for eksempel etiske prinsipper, etiske verdier, etiske problemer og etiske dilemmaer. 
Det kan handle om at man forbinder etikken med svevende teorier som er vanskelige å relatere til den virkeligheten vi jobber i. Eller det kan være at vi ikke snakker nok om etikk, at vi rett og slett ikke har trent oss på å bruke det etiske språket, og at det derfor er fremmed for oss.

\section{«For å bli god i et språk må vi bruke det.»}

For å bli god i et språk må vi bruke det. For å bli god på det etiske språket og på å stille de etiske spørsmålene må vi snakke det så ofte vi kan. Vi må for eksempel øve oss på å sette ord på hva etiske verdier og prinsipper er, og på hvilke etiske verdier og prinsipper vi mener er viktige å ivareta. Og vi må Øve oss på å formulere etiske problemer og dilemmaer.

I etikkspalten denne gangen vil jeg ta for meg to helt grunnleggende begreper i etikkspråket - begrepene «etisk problem» og «etisk dilemma». Jeg skal prøve å få frem hva som kjennetegner et etisk problem og et etisk dilemma. Hvis vi vet hva som kjennetegner et etisk problem, vil det hjelpe oss med å identifisere disse problemene. Videre prøver jeg å få frem forskjellen på et etisk problem og et faglig problem.

\section{Hva er etiske problemer og etiske dilemmaer?}

Kort sagt kan vi si at et etisk problem er et problem der etiske verdier eller prinsipper blir utfordret eller kommer i konflikt, der du blir usikker på hva som er riktig å gjøre, og hva som er det beste for pasienten (1).

Du kan for eksempel stå i en situasjon hvor pasienten ikke ønsker behandling, og du er i tvil om du bør ta hensyn til pasientens medbestemmelse, eller om pasientens liv og helse er viktigere. Eller det kan handle om at du og dine kolleger er uenige om hva som er riktig eller er til det beste for pasienten, hvilke verdier eller prinsipper man bør prioritere. 
Jeg tenker på begrepet «etisk problem» som en sekkebetegnelse for problemer og utfordringer som handler om verdier vi ønsker å ivareta. Det kan også innebære problemer og utfordringer som det er mulig å finne en optimal løsning på, men som kan kreve at vi sorterer og reflekterer over problemet, før vi finner løsningen.

Et etisk dilemma, derimot, er en form for etisk problem der det ikke finnes noen optimal løsning. Et typisk eksempel kan være når du som sykepleier må prioritere mellom pasienter. Når du prioriterer, betyr det at du må si nei til noen eller noe. Det at du prioriterer en foran en annnen, betyr at de eller den som nedprioriteres, kanskje ikke får den optimale omsorgen eller behandlingen.

\section{Vi skiller mellom faglig og etisk problem}

Videre vil jeg skille mellom det jeg kaller faglige problemer og etiske problemer. Jeg møter noen ganger sykepleiere som hevder at «etikken er i alt», og at det ikke er mulig å skille mellom faglige og etiske problemer. Fag og etikk henger sammen og kan ofte være vanskelige å skille, men å si at «etikken er i alt», hjelper oss ikke med å sette ord på det etiske. Det er heller med på å tilsløre det etiske og gjør det enda vanskeligere å sette ord på etikken og bruke det etiske språket.

\section{«Ikke alle utfordringene vi opplever som sykepleiere, handler om etikk.»}

Ikke alle utfordringene vi opplever som sykepleiere, handler om etikk. Når vi vurderer hvilken type sårbehandling en pasient skal få, eller hvordan vi utfører en behandling, trenger vi ikke alltid etikken for å svare på det. Her har vi fagkunnskap om sår og sårbehandling som kan hjelpe oss. 
Det kan imidlertid utvikle seg til et etisk spørsmål eller problem dersom etiske verdier eller prinsipper

kommer i konflikt når du skal utføre sårbehandlingen.

Det kan for eksempel handle om at pasienten motsetter seg behandlingen, men at du som sykepleier mener behandlingen er viktig for å ivareta pasientens liv og helse.

\section{Hvorfor er det så viktig å bruke det etiske språket?}

For å kunne handle til det beste for pasienten og unngå å krenke pasienten må vi kunne identifisere situasjoner der viktige verdier og prinsipper utfordres. Når du kjenner på at noe er galt, har du et ansvar for å stille spørsmål ved det som skjer. Og du har et ansvar for å gjøre noe med det du reagerer på.

Ved å øve deg på å sette ord på det som er etisk problematisk i situasjonen, $\varnothing$ ver du deg samtidig på å bruke det etiske språket, og du kan bidra til en større bevissthet rundt etiske spørsmål i avdelingen du jobber på.

\section{«Moralsk sensitivitet er en evne som kan øves opp når du øver deg på det etiske språket.»}

En annen viktig grunn til at det er viktig å bruke det etiske språket og stille etiske spørsmål, er at du da er med på å holde den moralske sensitiviteten din ved like (1). Moralsk sensitivitet handler om evnen til å bli oppmerksom på moralske verdier og prinsipper som berøres i en situasjon (2). Da må du bruke både det kognitive og følelsene dine i situasjonen.

En dårlig magefølelse kan for eksempel gjøre deg oppmerksom på at du står overfor et etisk problem eller dilemma. Da må du bruke dine rasjonelle og faglige kunnskaper og det etiske språket for å kunne sette ord på det. Moralsk sensitivitet er en evne som kan øves opp når du øver deg på det etiske språket. 


\section{Konklusjon}

Vi trenger moralsk bevisste og modige sykepleiere, med en moralsk sensitivitet, som tør å stille de etiske spørsmålene. For å beholde og utvikle den moralske sensitiviteten må vi som sykepleiere øve oss på å bruke det etiske språket.

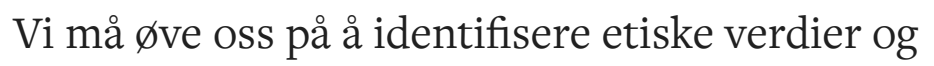
prinsipper vi mener er viktige for å kunne utøve en moralsk forsvarlig og god sykepleie til det beste for pasienten.

I en artikkel som $i$ løpet av høsten 2021 vil bli publisert $i$ tidsskriftet Nursing Ethics, beskriver vi hvordan sykepleieledere strever med à sette ord på etiske utfordringer: Storaker A, Heggestad AKT, Sceteren B. Ethical challenges and lack of ethical language in nurse leadership. Akseptert 6.mai 2021 for publisering $i$ Nursing Ethics.

\section{Referanser}

1. Heggestad AKT. Etikk i klinisk sjukepleie. Oslo: Samlaget; 2018.

2. Lützén K, Dahlqvist V, Eriksson S, Norberg A. Developing the concept of moral sensitivity in health care practice. Nurs Ethics. 2006;13(2):187-96. 